\title{
Research on the Methods of Integration Ideological and Political Education Into Physical Education Curriculum in Higher Vocational Colleges
}

\author{
Linfei Qiu, Guocan Ren*
}

Ningbo City College of Vocational Technology, Ningbo, Zhejiang, China

*Corresponding author

\begin{abstract}
Ideological and political education is the core course in our education system. The integration of ideological and political education into the physical education curriculum is a powerful measure to further improve students' ideological and political consciousness, enhance students' professional quality, and cultivate high-quality and skilled talents for the country. This paper expounds the feasibility and necessity of the integration of higher vocational physical education course teaching and ideological and political education, and puts forward the methods and ways to integrate ideological and political education into physical education course teaching based on the actual situation of physical education in higher vocational colleges in China, and puts forward a new idea for the organic integration of physical education and ideological and political education.
\end{abstract}

Keywords: Education, Method, Ideology

\section{INTRODUCTION}

To thoroughly implement the national education policy, comprehensively implement the spirit of ideological and political and sports work conferences in universities across the country, provinces, and cities, give full play to the role of physical education in ideological and political education, fully implement the school's strict management of education, strict management of science, and achieve meticulous care. Organize teaching, cultivate high-quality and highly-skilled personnel with socialist ideas with Chinese characteristics, and comprehensively improve the quality and level of school teaching. School education integrates ideological and political education into curriculum teaching, strives to build an education system with comprehensive development of morals, wisdom, and body, and establishes the education concept of health first, so that students can improve their physical fitness and physical fitness while exercising in physical exercise will.

\section{IMPORTANCE AND NECESSITY OF INTEGRATING PHYSICAL EDUCATION CURRICULUM INTO IDEOLOGICAL AND POLITICAL EDUCATION}

As important ideological and theoretical positions, We must hold high the great banner of socialism with Chinese characteristics, In-depth study and implement of General Secretary $\mathrm{Xi}$ Jinping's important speech on higher vocational education, and firmly focus on the fundamental question of "what kind of people, how to cultivate, and for whom." , Fully implement the Party's education policy, adhere to the direction of running socialist schools, take Ledder as the root, take ideal and belief education as the core, and take socialist core values as the guide. Give full play to the role of the main channel of classroom education, so that each door We must keep a good course and plant a field of responsibility, so that all courses have the function of educating people, all teachers have the responsibility of educating people, and train qualified and qualified builders of socialism with Chinese characteristics and comprehensive development and reliable succession people.

Students at this level have the characteristics of poor academic performance and low enthusiasm for learning. All educational activities in school teaching are closely focused on the development of students, so educating people is an important theme in higher vocational education. Physical education in higher vocational education can be used as an important part of ideological and political education in higher vocational education. The physical skills training, will training, and personality building in the physical education curriculum are highly consistent with many contents in ideological and political education in higher vocational education. The inherent culture contained in physical education also determines that it can become a platform and carrier for ideological and political education, and can provide more abundant spiritual and material resources for ideological and political education. Different from traditional theoretical education and preaching education, physical education courses can better stimulate 
students 'enthusiasm for learning, mobilize students' enthusiasm and emotions, and thus achieve unified education of emotion and rationality. Unity of Knowing and Doing."

\section{WAYS AND METHODS OF INTEGRATING PHYSICAL EDUCATION CURRICULUM INTO IDEOLOGICAL AND POLITICAL EDUCATION}

\subsection{Update Teaching Philosophy}

Looking at the current status of physical education in higher vocational education in China, it is found that moral education and physical education tend to be marginalized in the higher vocational education system. As a result, led to the lagging of many higher vocational physical education teachers' teaching concepts and the organic combination of ideological and political education and physical education without sufficient knowledge, the important understanding of physical education is insufficient, and the understanding of the spirit of sports and moral education is lacking. Physical education is biased toward skill teaching.

The change of teaching concept is the basis for the integration of ideological and political education and physical education. However, the teaching concept of most vocational $\mathrm{PE}$ teachers is lagging behind, which makes many teaching reform measures unable to be effectively implemented. According to the "Notice of the Ministry of Education of the Central Committee of the Communist Party of China on Further Strengthening the Situation and Policy Education of College Students (Jiaoshezheng [2004] No. 13), in order to strengthen and improve the ideological and political education of college students, the ideological and political work runs through the entire process of education and teaching. Integrate the ideological and political elements contained in all courses and the ideological and political education functions they carry into each link of classroom teaching to achieve the organic unification of ideological and political education and knowledge system education. Physical education teachers in higher vocational colleges must realize that physical education is an important part of ideological and political education and has a high degree of consistency with ideological and political education. It is necessary to firmly establish the "people-oriented" educational concept, to effectively educate people throughout the entire teaching process, to form a comprehensive and three-dimensional educational structure, and to explore an ideological and political theme of educating people with a focus on student development.

\subsection{Integrate Classroom Teaching Content}

From a theoretical point of view, there seems to be a seamless connection between ideological and political education and physical education, but in the actual teaching process, it is not the depth of theoretical inquiry or the pertinence of theoretical research that determines the final teaching effectiveness, but whether the teaching content is reasonable Whether it can make physical education continue to advance in the direction of ideology and politics. In the course of physical education teaching, we must optimize and integrate the teaching content, explore and meet the actual needs of higher vocational students, and integrate ideological and political theory teaching into the process of physical education. We must actively reflect on the content of ideological and political education.

\subsection{Innovative Teaching Methods}

At present, physical education, knowledge teaching, and "free" teaching in higher vocational colleges cannot reflect the essential characteristics of physical education and cannot play the ideological and political role of physical education. Therefore, its teaching methods must be innovative and reformed. It is necessary to further promote the reform of physical education teaching and continuously innovate teaching method.

In physical education, to allow students to better master the technical essentials, students need to practice repeatedly. Teachers 'observation, encouragement, and recognition are the driving force for students' progress and the process of ideological and political education for students. In this process, in addition to explaining the demonstration, teachers also need to infiltrate the content of ideological and political education. By combining the philosophy of life and some abstract metaphors, students can build the connection between physical education and ideological and political education. Physical education teachers have the obligation and responsibility to combine the teaching process with the improvement of students 'comprehensive quality, and cultivate students' good style of bravery, decisiveness, triumph, and defeat, so that students can gain a sense of accomplishment in sports and achieve sublimation of moral qualities.

\subsection{Reform the Assessment and Evaluation System}

Course evaluation directly determines the improvement of teaching content and the improvement of teaching quality. Teaching is a systematic process completed by teachers and students through effective communication, exchange and collaboration. In this process, there must be a reasonable and scientific evaluation and assessment method to reveal the effectiveness and shortcomings of physical education. The traditional higher vocational college education system has resulted in the failure to implement evaluation and assessment measures in higher vocational physical 
education, and it is impossible to form a joint force between management and physical education teachers. Establish and improve a scientific, comprehensive and accurate examination assessment evaluation system, focusing on process and results, and form a scientific evaluation system combining process assessment and final assessment at the end of the period. The evaluation standards of physical education courses in higher vocational education must define the evaluation content and evaluation standards of physical education and ideological and political teaching, build a systematic evaluation system, actively invite students, parents, and the society to participate, and improve the evaluation feedback mechanism for higher vocational physical education teachers The management should always understand the actual teaching situation, continue to put forward suggestions for higher vocational physical education teachers, and uphold the principle of "because of the new situation, the new situation," so that physical education teachers in the teaching practice continue to learn lessons and promote physical education Teacher development.

\subsection{Strengthen the Construction of Teachers}

For physical education teachers, the integration of ideological and political education and physical education teaching is undoubtedly a new challenge. Compared with the traditional education teaching model, the integration of ideological and political education and physical education requires physical education teachers to infiltrate the ideological and political education concepts and contents in the teaching process, and at the same time, students should build correct ideological values through physical activities. Under the influence of the traditional higher vocational physical education teaching model, many teaching workers have formed a fixed teaching thinking, and their teaching ability and knowledge level need to be mentioned. Therefore, under the requirements of the integration of ideological and political education and physical education, physical education teachers must improve their business abilities and ideological and political literacy. Schools must provide teachers with opportunities and time for further study, and new teachers must be qualified before they can be hired. And select a full-time teacher as a mentor to help them grow.

\section{CONCLUSION}

Ideological and political education, as an important part of today's education system, is a long-term, systematic education of people. It plays an important role in social development and the improvement of education. Physical education and ideological and political education have their own points of integration. The organic combination of the two is an important way to improve the teaching level of higher vocational colleges and an important measure to implement national, provincial and municipal educational decision-making. Therefore, higher vocational physical education teachers must change the traditional teaching concept and take the responsibility of students' ideological and political education. This is the inevitable trend of the development of higher vocational education, and it is also the new requirement of social development for higher vocational education.

\section{REFERENCES}

[1] Dajing Xie, The Necessity and Approach of Integrating Higher Vocational Physical Education Course into Ideological and Political Education, J, Journal of Beijing Polytechnic, 2019 (4) 80-83.

[2] Shuo Zhang, At the National Education Conference, Xi Jinping emphasized the adherence to the road of the development of socialist education with Chinese characteristics to cultivate socialist builders and successors of the comprehensive development of moral intellectual physical and aesthetic, N, People's Daily,2018-09-11 (1).

[3] Mi Chen, Preliminary Exploration of the Approaches to Realizing Quality Education in Physical Education in Higher Vocational Colleges, J, Sports World (Academic Edition), 2017 (4) 171-172.

[4] Nanli Tang, The Reflection and Function of Ideological and Moral Education in Physical Education in Higher Vocational Colleges, J, Curriculum Education Research, 2018 (35) 71.

[5] Min Liu, On the Complementary Paths of Ideological and Political Education and Mental Health Education in Higher Vocational Colleges, J, Comparative Research on Cultural Innovation, 2017 (24) 8-9.

[6] Hejiang Tong, Preliminary Study on the Significance of Fusion of Basketball Culture in Higher Vocational Basketball Teaching, J, Contemporary Sports Science and Technology, 2017 (16)139-141.

[7] Jun Mai, Exploration on the Realization of the Combination of Higher Vocational Sports and Humanities Education, J, Guangxi Education, 2017 (27) 171-172.

[8] Maoping Zuo, Research on the Integration of Craftsman Spirit Cultivation and Ideological and Political Education in Higher Vocational Colleges, J,Science and Education Wenhui (1st Issue), 2018 (6) 115-116. 
[9] Liqin Sun, Research on PE Curriculum from the Perspective of Professional Characteristics in Higher Vocational Colleges, J, Sports World (Academic Edition), 2017 (1) 153-154. 